\title{
Determinants Of Innovative Capability Of A Country And Its Role In Economic Growth
}

Faye Hall Jackson, Tuskegee University, USA

Tejinder Sara, Tuskegee University, USA

Simran K. Kahai, John Carroll University, USA

\begin{abstract}
This paper discusses the role that innovation plays in global competition and provides examples showing how firms from selected emerging markets use innovation to compete with global firms from the developed world. This paper also discusses the role of innovative capability in growth of a country by suggesting that in the long-term, a nation's higher order competitive advantage can only be built with the innovative capability of its firms. In this context, an empirical model was used to identify the determinants of innovative capability of a country. The discussion of these determinants should be useful to policymakers in countries attempting to promote economic growth by improving the productivity of firms in their respective countries.
\end{abstract}

Keywords: Global Competition; Innovation; Economic Growth

\section{INTRODUCTION}

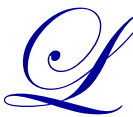

ong-term economic growth and prosperity of a country are often linked to competitive technology and innovation. In its "The Global Competitiveness Report 2008-2009," the World Economic Forum concluded that, "in the long-run, standards of living can be expanded only with technological innovation" (Sala-I-Martin, Blank, Drzeniek-Hanouz, Geiger, Mia, \& Paua, 2008). In the last two decades, Michael Porter's research on the broad question of how an economy progresses has received a great deal of attention. In an in-country research in ten countries, Porter studied the patterns of industry success as well as the impact of national policies on the achievement. Based on his research, Porter concluded that "economic prosperity depends on the productivity with which national resources are employed" (Porter, 1990). In his model, Porter discusses four distinct stages of national competiveness - factor-driven, investment-driven, innovation-driven, and wealth-driven. He asserts that a nation makes advances in the first three stages and the fourth stage is "of drift and decline." Thoughts on the fourth stage may align with the natural progression of capitalism and Darwinian thoughts of survival of the fittest. Many of the advantages in the first two stages are static and passive. These advantages can be imitated by firms in other countries. The advantages resulting from the innovation-driven stage upgrade the competitive position of a country's firms. Countries in the innovative-driven stage also tend to be less vulnerable to macroeconomic fluctuations and external shocks, such as currency and commodity price fluctuations.

In a 2010 report, Boston Consulting Group (BCG) concluded that over a three year period, innovative companies outperformed others in their industry by $12.4 \%$. This finding supports the thought that innovation is a key determinant of organizational success. The BCG report also presented results from a survey of 1,590 top executives from companies around the globe. In its findings, $72 \%$ of the respondents included innovation among the top three priorities and $84 \%$ of respondents said innovation will be a key part of their strategy to benefit from the economic recovery. The results of the survey reveal that top executives of companies around the globe believe innovation will play a key role in positioning organizations for competitive advantage and profitability. Of note is the increased need for technological innovations, both as service delivery portals and end-user consumable goods. These executives realize that the adage 'business as usual' is a recipe for failure and will only encourage competitors to take market share from existing organizations. For the developed or developing country, the global competitive landscape has seen change during the first decade of the twenty-first century. Companies from developing countries are using innovative ideas and techniques to compete in the global marketplace. In some instances, the changing competitive landscape has significantly affected the nations GDP. 
Conventional wisdom holds that cutting-edge high-end products were designed, produced, and marketed by knowledge-intensive companies in North America, Europe, and Japan. As such, it was assumed that companies in these countries would continue to be global leaders in design and manufacture of innovative products and that lowend knockoffs of the innovative products will be the province of companies in the emerging markets. However, the first decade of the twenty-first century has witnessed a move up the global value chain by companies from the emerging markets. Each year since 2005, Bloomberg Business Week has published annual rankings of "The 50 Most Innovative Companies" globally. In early years, companies from North America, Europe, and Japan dominated the list. As shown in Table 1, only two companies from emerging markets (one each from South Korea and India) appeared in the year 2006 list. Companies from the United States dominated the list in early years (with 30 in 2006), but companies from emerging markets started to appear with more frequency in recent years. Table 1 shows the decrease in dominance of the US companies (with 22 in 2010) and increase in companies from emerging markets of Brazil, China, India, and South Korea. The new trend in innovation capabilities of companies in emerging market economies has been accompanied by another trend. For the first time in the last two centuries, the emerging market economies will contribute a larger percentage to the world economic growth compared to the developed countries (Bisson, Stephenson, \& Viguerie, 2010)

Table 1: Change in Home Base of the World's 50 Most Innovative Companies

\begin{tabular}{lcc}
\hline & $\mathbf{2 0 0 6}$ & $\mathbf{2 0 1 0}$ \\
\hline North America, Europe, \& Japan & 48 & 40 \\
Brazil, China, India, \& Korea & $2 *$ & $10^{* *}$ \\
$*$ South Korea, 1 and India 1 & & \\
$* *$ Brazil 1, China 4, India 2, and South Korea 3 & & \\
\hline Source: Business Week-BCG Survey http://www.businessweek.com/interactive_reports/most_innovative.html &
\end{tabular}

\section{BACKGROUND}

Conventional solutions, by focusing mostly on economic aggregates, have failed to address the main causes of low economic growth and poverty in a number of countries. Since individual firms create jobs and growth in a country, it is essential to study the functioning of these firms to include operations strategies, logistics, and succession planning. If the firms in a country are productive and growing, the country, in aggregate, will have a higher growth rate. Thus, the key to a country's prosperity is the sum productivity of its individual firms. Many a times, studies on economic prosperity of countries focus only on macroeconomic variables, such as budget deficits, interest rates, tariffs, etc. While there is no denying that these are important variables for growth, the root causes of productivity must be understood and replicated so that sustained growth of the firms can be enjoyed. Even though improvements in human capital, infrastructure, institutions, and macroeconomic variables have shown to contribute to economic growth, these factors eventually succumb to the law of diminishing returns (World Economic Forum, 2005). In today's age of global competition, sustained national economies' progress is experienced by "upgrading and extending competitive positions through higher order competitive advantages in existing industries and developing the capability to compete successfully in new, high productivity segments of industries" (Porter, 1990). In the long run, a nation's higher order competitive advantage can be built only with innovation. A nation's firms must use technical innovation to develop cutting-edge products and processes. In Porter's innovative-driven competitiveness discussed above, firms not only create technology, but also acquire and refine technology available in other nations for use in their operations. This is because globalization has brought down geographic and market boundaries, thereby improving a company's ability to innovate by borrowing ideas from other countries. This globalization, in large part, is responsible for innovative growth in emerging markets. In a recent survey by McKinsey and Co., seventy percent of the senior executives said that innovation will be one of the top three drivers of growth in their company in the next three to five years (Barsh, Capozzi, \& Davidson, 2008). In another survey, executives viewed innovation as the most important way for companies to stay competitive in today's global business environment (The McKinsey Quarterly, 2006).

Neoclassical economic theory does not emphasize entrepreneurial activity and fails to explain why a nation's firms gain competitive advantage that is not based on its endowment of factors. In other words, theory of comparative advantage does not explain why firms in some nations are better at product designs and have more efficient use of resources that lead to high and rising productivity. Neoclassical theory, which is based on the assumption of perfect competition between firms producing similar products with similar inputs, prevents individual 
firms from raising the price of its output to more than what covers the costs of its inputs and a fair return to the investors. It assumes that all activity involves making old products with old technology (Morck \& Yeung, 2001). Introduction of innovation violates the assumption of perfect competition. Innovation includes not only designing and producing new and better goods for which firms can charge higher prices compared to their competitors, but cheaper ways of producing existing goods. In either case, innovative firms can earn profits in excess of their input costs. Many decades ago, Joseph Schumpeter had recognized that competition was constantly changing (Schumpeter, 1934). He postulated that there is no such thing as "equilibrium" in competition. According to Schumpeter's insight, innovative firms bring new products or better technology into the economy. Innovative firms destroy stagnant firms. Even though the "destruction" of stagnant firms can be considered a negative impact of innovation, it can lead to higher productivity and national competitive advantage that is more durable. National advantage based on factor costs is easy to replicate, but higher order advantage that can, for example, help establish brand name products can be difficult to replicate and bring competitive advantage to a country's firms. In some sense, innovative firms display a Darwin-like tendency of 'survival of the fittest'. As an illustration, in early years of development, Korean electronic firms had not developed sustainable advantages and competed on the basis of labor costs, but this advantage started eroding when Japanese, American, and European firms started manufacturing operations in other Asian countries, such as Malaysia, Indonesia, and Thailand. In response to this threat, Korean firms, such as Samsung, used innovation to develop cutting-edge products and processes that propelled Korea to the level of a developed country. There have been a number of studies that support the view that there is a positive relationship between innovation and growth of countries. For example, a Canadian study shows that correlation between a country's log per capita GDP and the log of the number of patents its residents hold normalized by GDP is +0.69 , significant at the 0.001 level (Morck \& Yeung, 2001). Other studies that support this view are Jacobs (1984), Porter (1990), and Romer (1994). Given innovation's role in economic growth of countries, it is important to understand the factors that are conducive to innovation activity in a country. The next section discusses these factors and also presents an empirical model to test the relationship between these factors and innovation.

\section{DETERMINATION OF INNOVATION}

Peter F. Drucker, considered by many to be the father of "modern management," has predicted many of the major developments of the late twentieth century and, over the years, provided consulting services to leading corporations around the world. In one of his insights, Drucker pointed out that innovation is not a "flash of genius," but hard work by firms and individuals of a country (Drucker, 2001). This means that there has to be proper conditions in a country whereby "hard work" by firms and individuals will result in innovations. The proper conditions are rooted in macroeconomic variables that create an environment for the hard work and preparation to be transformed into innovative opportunities. It is believed that innovative capability of a country is determined by quality of macroeconomic environment that enables firms of a country to create valuable goods and services using efficient and innovative methods. Thus, this study identified eight variables that are considered to be important determinants of the level of innovation capability in a country. Below is a description of these eight variables and the sources of values for them.

\section{Sources and Selection of Variables}

For more than three decades, the World Economic Forum has studied and benchmarked many factors that can contribute to national competitiveness. The methodology has changed over the years by incorporating the latest thinking about what derives the underlying productivity of a nation. Since 2001, the methodology has been based on a model developed by Jeffery Sachs and John McArthur, called the Growth Competitiveness Index (GCI). The GCI uses a combination of hard data and that which is drawn from the World Economic Forum's Executive Opinion Survey which attempts to capture concepts for which hard data may not be available but is essential for economic growth (for example, prevalence of institutionalized corruption, government waste, and enforcement of contracts and laws). In addition, it has data on other variables essential for competitiveness for a country's business firms. In the authors' view, among the factors identified by World Economic Forum in its study of global competitiveness, seven of the eight factors aid a country's firms to become innovative and productive. As discussed below, in recent years some researchers have argued that excessive government intervention in the economy crowds out private initiative and investment and discourages entrepreneurship. Thus, another variable measuring government size was also included as a possible explanatory variable for innovative capability of countries. The data on this eighth 
variable - government size - were obtained from the "2008 Index of economic Freedom" compiled by the Heritage Foundation. All eight variables are discussed below and Table 2 provides variable names and definitions for data used in the empirical model. Usable data for 121 countries were obtained from the two data sources discussed above.

\section{Description of the Variables}

\section{Institutions}

The interdependent relationships of composite institutional factors frame the economic potential of innovative economies. Some researchers have contended that the rules of games in a society matter most in creating appropriate incentives for desirable economic behavior (Rodrik \& Subramanian, 2003). Over three hundred years ago, philosopher John Locke (2003); over two hundred years ago, economist and philosopher, Adam Smith (1994); and sixty years ago, economist Frederick von Hayek (1944) emphasized the importance of property rights in productivity and economic success of nations. Adam Smith said, "Nations will experience opulence and peace once they create the institutions that encourage entrepreneurship and savings." Recent work on the role of institutions in economic growth has been associated with the writings of Nobel Prize winner economist Douglas North (1990). North emphasized the affect of institutional factors on economic development and concentrated on the relationship between economic growth and two institutional factors; namely, political freedom and civil liberty. More recently, Morck and Yeung have contended that institutions that protect intellectual property rights determine the pace of innovation in a country (Morck \& Yeung, 2001). Consistent with historical perspective and present trends, a positive relationship is expected between innovation capability of a country and the quality of institutions in that country.

\section{Business Sophistication}

Business sophistication depends on a country's quality of business networks and supporting industries. A country with a network of suppliers and firms with high quality operations and strategies will create opportunities for innovations. A positive relationship is expected between innovation capability of a country and its business sophistication.

\section{Government Size}

For a long time, the private sector has been at the forefront of funding successful innovations (Morck \& Yeung, 2001). On the other hand, government efforts in spurring innovations have been rather dismal. In the 1980s and 1990s, Japan's Ministry of International Trade (MITI) was credited with financing a number of successful Japanese firms, but a 1996 study showed that most of the firms subsidized by MITI were not productive and sustainable in the long run (Beason \& Weinstein, 1996). Economists have recognized that, in many cases, excessive government expenditures can lead to inefficiency and loss of productivity in the country (Beach \& Kane, 2008). Government expenditures compete with private sector and divert resources through a crowding-out effect. Thus, a negative relationship would be expected between the size of the government and the pace of innovations in a country.

\section{Training and Education}

The quality of labor force in an economy is critical for competitiveness. In a fast changing global economy that requires technological adaptation by firms, a pool of well-educated employees provides opportunities for innovative capability. Thus, a positive relationship is expected between the quality and quantity of higher education provided in a country and innovation capability of that country.

\section{Technological Readiness}

Technological readiness refers to factors that increase technological capacity of a country. This includes stock of technology available in a country and the penetration rate of information and communication technologies. A positive relationship is expected between state of technological readiness of a country and innovation capability of that country. 
Market Size

A large market size gives firms incentive for productivity and expansion because in a large market, firms can exploit economies of scale. In a global economy, the market size includes the sum of the domestic market and opportunities for export. Larger market opportunities should give firms incentive to become innovative to take advantage of increased business opportunities. A positive relationship is expected between market size and innovation capability of a country.

\section{Labor Market Efficiency}

Efficient labor markets give firms the flexibility to recruit and allocate workers to the most productive tasks. It also allows the firms to provide incentives to workers based on their effort and productivity. This should result in firms and workers in efficient labor markets seeking innovative products and processes to increase productivity and profits. A positive relationship is expected between labor market efficiency and innovative capability of a country.

\section{Infrastructure}

Firms need good infrastructure such as dependable electricity supply, good and reliable telecommunications networks, and good transportation networks to develop and use innovative products and processes. Thus, a positive relationship would be expected between quality of infrastructure and innovative capability of a country.

\section{Empirical Model}

This section presents the empirical model that was used to describe the role of variables discussed in the previous section and innovation capability of a country. Table 2 presents the dependent variable (innovative capability of a country) and eight variables used to predict this variable. The World Economic Forum has been measuring national competitiveness for over two decades, so the World Economic Forum data were used for innovative capability of countries and seven of the eight independent variables. The data for 2008 includes 134 countries. The data on the eighth variable - government size - were obtained from the "2008 Index of Economic Freedom" compiled by the Heritage Foundation which was available for 157 countries. The authors were able to obtain usable data for 121 countries from these two data sources.

Table 2 provides variable names and definitions for data used for 121 countries. Results of regression for the empirical model are presented in the next section.

Table 2: Variable Definitions

\begin{tabular}{ll}
\hline Variable & \multicolumn{1}{c}{ Definition } \\
\hline INNOV & An index of innovative capability of a country (2) \\
INSTI & An index for quality of public institutions in a country (2) \\
BUS SOP & An index business sophistication of a country (2) \\
GOV SIZ & An index of government share in the GDP of country (1) \\
TRAIN/ED & An index of the quality of training and education of a country's labor force (2) \\
TECRED & An index of the quality of existing technologies in a country (2) \\
MKTSIZE & An index of the market size (domestic and international) available to the firms of a country (2) \\
LAMKEF & An index of the efficiency and flexibility of the labor market of a country (2) \\
INFR & An index of the quality of infrastructure of a country (2) \\
Sources: (1) 2008 Index of Economic Freedom, Holmes, Feulner, \& O'Grady, Heritage Foundation, Washington D.C. 2008. (2) The Global \\
Competitiveness Report 2008-2009: World Economic Forum, Geneva, Switzerland
\end{tabular}

The specification of the equation in the model is given below. All variables, except GOV SIZ, are expected to have positive signs. Results of the regression analysis are presented in Table 3.

INNOV = $\mathrm{f}($ INSTI, BUS SOP, GOV SIZ, TRAIN/ED, TECRED, MKTSIZE, LAMKEF, INFR) 
Table 3: Regression Results

\begin{tabular}{lccc}
\hline \multicolumn{1}{c}{ Variables } & Coefficient & T-Statistic & Significant \\
\hline INTERCEPT & -1.217 & -3.644 & .000 \\
INSTI & .143 & 2.189 & $.031^{* *}$ \\
BUS SOP & .576 & 5.272 & $.000^{*}$ \\
GOV SIZ & $-2.132 \mathrm{E}-03$ & -1.225 & .223 \\
TRAIN/ED & .102 & 1.149 & .253 \\
TECRED & $5.133 \mathrm{E}-02$ & .549 & .584 \\
MKTSIZE & $5.136 \mathrm{E}-02$ & 1.358 & .177 \\
LAMKEF & .229 & 2.857 & $.005^{*}$ \\
INFR & $-4.456 \mathrm{E}-03$ & -.592 & .555 \\
\hline
\end{tabular}

$\mathrm{R}^{2}=.886 ; \mathrm{F}=107.451 ; *$ Significant at the 0.01 level. **Significant at the 0.05 level

Empirical Results

Data from 121 countries were analyzed based on eight variables discussed in the previous section institutions, business sophistication, government size, training and education, technological readiness, market size, labor market efficiency, and infrastructure. Countries analyzed represented various stages of development.

The results of regression shown in Table 3 are encouraging. First, the test for overall model significance shows that the model is useful in predicting INNOV (the innovative capability of a country). The calculated value of $\mathrm{R}^{2}$ is 0.886 for the model. All coefficients, except INFR (infrastructure) for which a hypothesized sign was expressed, attained the predicted sign. Thus, the model of determinants of innovative capability of a country appears to perform satisfactorily.

With regard to the individual coefficients estimates, three variables proved to be significant determinants of innovative capability of a country ( $\mathrm{p}<0.05)$. These variables are BUS SOP (business sophistication in a country), LAMKEF (efficiency and flexibility of labor market of a country), and INSTI (quality of public institutions in a country). Four variables - TRAIN/ED (quality of training and education of a country's labor force), TECRED (quality of existing technologies in a country), MKTSIZE (market size available to the firms of a country), and GOV SIZ (government share in the GDP of a country) - have the predicted sign, but only two (MKTSIZE and GOV SIZ) are significant at less than 0.25 . Even though the coefficient for INFR (quality of infrastructure of a country) does not have the predicted sign, it is significant at 0.555 level. Thus, the role of the quality of a country's infrastructure in predicting the innovative capability of a country is inconclusive.

Based on the results of the empirical analysis, it can be concluded that the innovative capability of a country is most significantly affected by the quality of three variables - business networks and supporting industries (business sophistication) in the country, flexibility given to the country's firms to recruit and allocate workers to the most productive tasks (labor market efficiency), and the quality of a country's public institutions within which the economy's main players interact (institutions).

\section{CONCLUSIONS}

Over the years, a number of studies have come to the conclusion that economic prosperity of countries depends on the productivity with which national resources are employed. Since individual firms create jobs and growth in a country, it is essential to study the functioning of these firms. If the firms in a country are innovative and growing, the country, in aggregate, will have a higher growth rate. Thus, any discussion of growth of economies should focus on determinants of innovation capability of a country. In this paper, an attempt was made to look at the relationship between eight macro level variables and innovation capability of an economy. The results of the empirical model should be useful for policymakers in countries promoting economic growth by improving the productivity of the firms in their country. The policy focus should be in developing rules and regulations for improvement in the quality of public institutions, quality of business networks and supporting industries, and flexibility in the labor markets in their countries should be stressed. 


\section{AUTHOR INFORMATION}

Dr. Faye Hall Jackson graduated in 1985 from Tuskegee University with a Bachelor of Science degree. She received the MBA degree from Clark Atlanta University in 1988 and PhD from Auburn University in 1997. She has served on the faculty at New Mexico State University and the University of Houston. She currently serves as the Head of the Department of Management at Tuskegee University. E-mail: jacksonhf@ mytu.tuskegee.edu

Dr. Tejinder Sara graduated in 1969 from California State University, Los Angeles, with a Bachelor of Science degree in business and economics. In 1974, he received the PhD degree in economics from the University of Massachusetts at Amherst. He currently serves as the dean of the Brimmer College of Business and Information Science at Tuskegee University. E-mail: tsara@mytu.tuskegee.edu (Corresponding author)

Dr. Simran Kahai received the Bachelor of Arts degree in economics in 1987 from Panjab University, India. She received the Master of Science degree in economics in 1992 and a PhD in economics in 1995. Both of the graduate degrees were obtained from Auburn University. She currently holds the rank of Associate Professor of economics in the department of Economics and Finance at John Carroll University. E-mail: skahai@jcu.edu

\section{REFERENCES}

1. Barsh, J., Capozzi, et al (2008). Leadership and innovation. The McKinsey Quarterly, January.

2. Beach, W. W., et al. (2008) Methodology: Measuring the 10 Economic Freedoms. 2008 Index of Economic Freedom. Heritage Foundation, Washington D.C.

3. Beason, R., et al (1996). Growth, economies of scale, and targeting in Japan. Review of Economics and Statistics, 78, 286-95.

4. BusinessWeek.com (2010). The World's 50 most innovative companies. Bloomberg Businessweek. Retrieved May 17, 2013, from http://www.businessweek.com/interactive_reports/most_innovative.html

5. Bisson, et al. (2010, June). The global grid. Retrieved May 17, 2013, from http://www.mckinsey.com/insights/innovation/the_global_grid

6. Drucker, P. (2001). The essential Drucker: Best of sixty years of Peter Drucker's essential writings on management. Harper Collins. New York.

7. Hayek, F. V. (1944). The road to serfdom. London, Routledge Press.

8. Holmes, K. R., et al. (2008) Index of economic freedom. Heritage Foundation, Washington DC.

9. Jacobs, J. (1984). Cities and wealth of nations: Principles of economic life. Random House, New York.

10. Locke, J. (2003). Two treatises of government. London: Yale University Press.

11. Morck, R., et al. (2001). The economic determinants of innovation. Industry Canada Research Publications Program.

12. North, D. C. (1990). Institutional change and economic performance. New York, Cambridge Press.

13. Porter, M. (1990). The competitive advantage of nations. Free Press, New York

14. Rodrik, D., et al. (2003). The primacy of institutions. Finance and Development, 31-34.

15. Romer, P. (1994). The origins of endogenous growth. Journal of Economic Perspectives, Winter.

16. Sala-I-Martin, et al. (2008). The global competitiveness index: Prioritizing the economic policy agenda. The Global Competitiveness Report 2008-2009, World Economic Forum, Geneva, Switzerland 2008.

17. Schumpeter, J. A. (1934). The theory of economic development: An inquiry into profits, capital, credit, interest, and business cycle. Harvard Univ. Press, Cambridge, Mass.

18. Smith, A. (1994). An inquiry into the nature and causes of the wealth of nations. New York: Random House.

19. The McKinsey Quarterly (2006). An executive take on the top business trends: A global McKinsey survey. April.

20. World Economic Forum (2005). The global competitiveness report 2005-2006: Policies underpinning rising prosperity. Geneva, Switzerland.

21. World Economic Forum (2008). The global competitiveness report 2008-2009. Geneva, Switzerland. 
NOTES 